\title{
Study on the Management Certification and the Process Management of the Carbon Sequestration and Utilization
}

\author{
Hui Ma \\ Information School of Capital University of Economics and Business Beijing, 100070, China \\ mahui@cueb.edu.cn
}

\begin{abstract}
With the attention paid to the management of carbon emission, the technology of carbon sequestration and utilization has become hot technologies and integrated disciplines. In addition to technical issues, risks and effectives are concerned. On the basis of CCUS exploring, drawing the references from CMM, this paper studies and discusses the level of CCUS risks and the certification and maturity of management.

Index Terms - CCUS, Risk Management, Certification, Process Management
\end{abstract}

\section{Introduction}

CCUS ( Carbon Capture, Utilization and Storage ) means to collect the carbon emission from emission sources such as large scale power plants, iron and steel works and chemical plants by means of using various methods to store and rationally utilize emissions to avoid emissions discharging to the atmosphere. It includes elements of carbon dioxide capturing, transporting and sequestration. See Figure 1. The CCUS technology is the latest development of CCS (Carbon Capture and Storage ) and a tendency, namely it is not merely sequestration but purifies and sequestrates carbon dioxide, and further put it into a new production process.

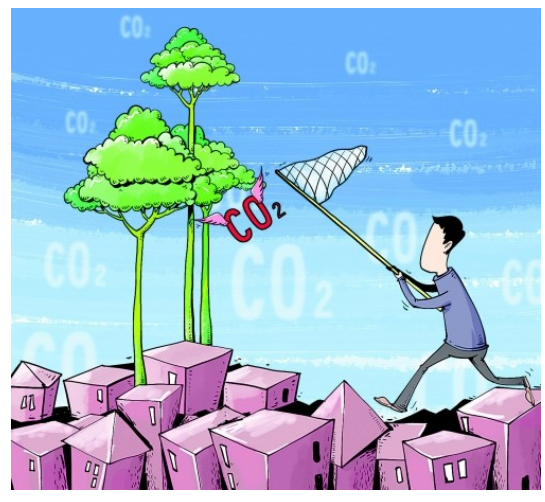

Figure 1. Carbon Capture(From CFP)

Burying carbon dioxide is an effective way to avoid climate change. Research results of Intergovernmental Panel on Climate Change (IPCC) show that $99 \%$ buried carbon dioxide can be stored about thousand years if the burying place is elaborately selected, designed and managed, for the stable character of carbon dioxide. Possible burying places are mainly such as depleted oil and gas reservoirs, deep salt water bearing reservoirs, unworkable coal bed and deep sea etc.
In China, the carbon dioxide flooding has big potential, ripe condition and relative rich resource. Meanwhile some results and experiences have been gained. The CCUS Demonstration Project Experience Exchange Conference held by the Department of International Cooperation of the Ministry of Science and Technology of the People's Republic of China, the carbon sequestration Leadership Forum Secretariat (CSLF) and the Administrative Center for China's Agenda 21 was held in Beijing successfully. The experts and representatives of relevant government departments of CSFL members, Global Carbon Capture and Storage Institute (GCCSI), International Energy Agency (IEA) etc were present the conference. In September 2011, the Administrative Center for China's Agenda 21 of the Ministry of Science and Technology of the People's Republic of China published "Carbon Capture , Utilization and Storage Technology Development in China" and the "Technology Roadmap Study on Carbon Capture , Utilization and Storage in China",

\section{Multi-dimensions Analysis of CCUS}

There are various elements that influent the effect of the carbon sequestration and utilization. Include mainly are technology, law and regulation and management in context. See Figure 2

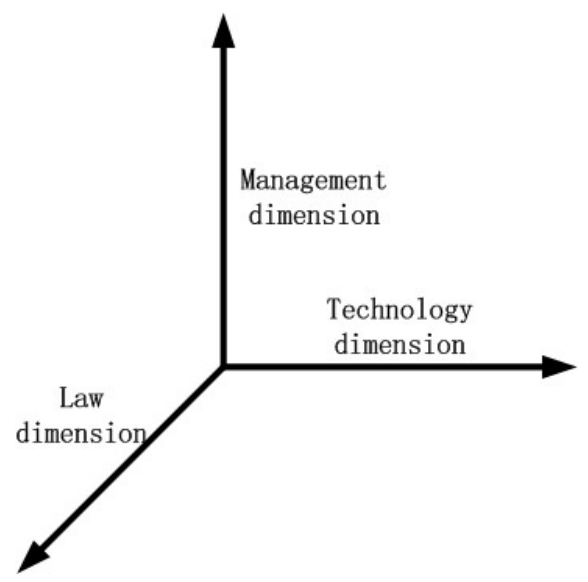

Figure 2 Diagram of CCUS Managemen

Because of the limitation of space, here mainly discusses technical issues. There are some samples of laws and regulations such as the Offshore Petroleum Amendments (Greenhouse Gas Storage) Act 2008 of Australia for the requirements of ocean greenhouse gases sequestration; the 
Norwegian Pollution Control Act which stipulates the carbon emission of plants as pollutant and the permission required for large carbon emission companies. For the relevant rules and regulations refer to the table 1.Hereafter we will focus on the analysis of management.

Table 1 Rules and Regulations of Carbon

\begin{tabular}{|c|c|l|l|}
\hline No. & Date of Issue & Name & China's Particepation Situation \\
\hline 1 & 1992 & $\begin{array}{l}\text { UN Framework } \\
\text { Convention on } \\
\text { Climate Change }\end{array}$ & 1993 China ratified the Protocal \\
\hline 2 & 1997 & Kyoto Protocol & $\begin{array}{l}\text { August,30th 2002, China ratified } \\
\text { the Protocal }\end{array}$ \\
\hline 3 & 1982 & $\begin{array}{l}\text { the United Nations } \\
\text { Convention on the } \\
\text { Law of the Sea }\end{array}$ & 1996, China ratified the Protocal \\
\hline 4 & 1972 & London Convention & $\begin{array}{l}\text { China join the Convention in } \\
1985 .\end{array}$ \\
\hline
\end{tabular}

In the regard of the assessment and certification of the management, it is at the preliminary stage in world wide. However, the standardized management and the third party certification are necessary and even vital. Besides, included supports are risk and process management.

\section{Using CMM for the quality certificating of CCUS management and Developing Management Maturity level}

SW-CMM—Software Capability Maturity Model (CMM) is a set of standards to value software ability and mature degree that is researched by the Software Engineering School of Carnegie Mellon University (SEI). On the basis of results of many software experts practice experiences, the standard place emphasis on the developing and assessing of abilities of management and engineering during the software development. It is the international popular process standard of software production and the certification standard of enterprises maturity level. It provides a stepped frame for software organizations to improve their software ability and there are 5 grades: grade 1, the initial grade; grade 2, the repeatable grade; grade 3, the defined grade; grade 4 , the managed grade; grade 5 , the optimizing grade.

Like other technologies, there are risks, including technology risks and management risks, in applying CCUS technologies. Therefore, we could take the principles and contents of CMM modules as reference to mitigate risks.

\section{A. Using CMM to Develop CCUS Management Maturity Level}

Based on CMM, the CCUS management is divided into 5 grades, namely the chaos grade of carbon emission management (no management of CCUS, random), repeatable grade (standardized management of CCUS), the defined grade (the management of CCUS with consistency), the measureable grade (the quantitative management of CCUS) and the optimizing grade (predictable and controllable of CCUS).

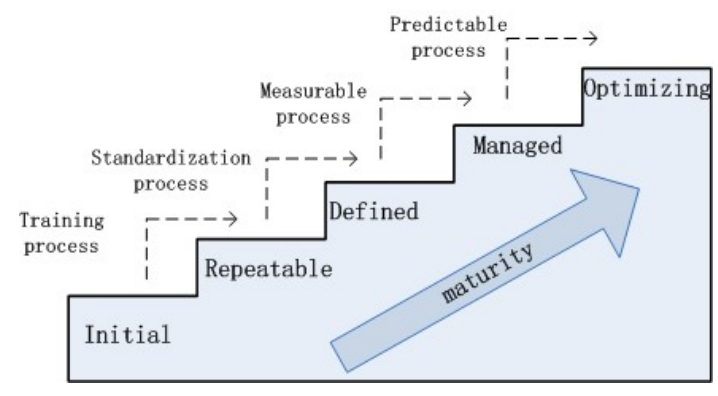

Figure 4 Five Grades Management Ability of CCUS

\section{B. Avoid management risk using CMM}

We must admit that too many software developments failed. Over the past years, although most projects worked out their blueprints and milestones in the beginning and even provided a series of documents (for instance, the logic model, physical model, and etc), they turned out to fail in over-budget and poor quality eventually due to improper and inefficient management and control methods. A huge investment of manpower, materials, and money was wasted. Project management is still difficult. Sun $\mathrm{Zi}$, an ancient Chinese strategist, said that to know one's own strength and the enemy's is the sure way to victory. For software project managers, the "enemy" here just refers to the risk. In information industry, it is a usual phenomenon that two experts hold different or even opposite analyses to a same project but both with sufficient evidences. This exactly reflects the specialties and risks of information industry. In the following we will discuss typical problems in software development and explore the main thoughts of margining technology.

In fact, the above-mentioned problems only reflect some phenomenon that is superficial while overlooking the usually hidden problems such as the chaos and immaturity of internal management which often lead to more risks and serious losses. Figure 5. describes how the weak management leads to great risks.

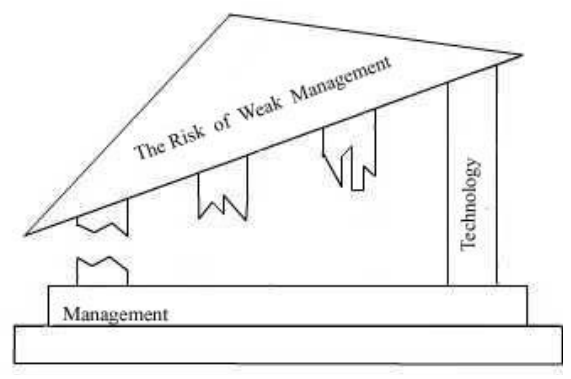

Fig.5 weak manages is to cause risk

The typical problems in project management mainly include: delay of product delivery, unexpected expansion of project scale and increasing cost, inability to meet the demand of customers for products, poor quality of subcontractors and the weakness, disorder and loopholes that they aroused, and 
inability to control the entire project. According to Table 2, all these common problems in software management fall into three groups: 1) resources or cost, 2) progress, and 3) quality.

Table 2 Typical problem description in CCUS Projects

\begin{tabular}{|c|c|c|}
\hline $\begin{array}{l}\text { Problem } \\
\text { classification }\end{array}$ & $\begin{array}{l}\text { Typical problem } \\
\text { description in Software project } \\
\text { management }\end{array}$ & $\begin{array}{l}\text { Typical problem } \\
\text { description in CCUS } \\
\text { Projects }\end{array}$ \\
\hline \multirow{4}{*}{$\begin{array}{l}\text { Resource (cost) } \\
\text { problem }\end{array}$} & Cost / budget problem & $\begin{array}{l}\text { Trapping sequestration, } \\
\text { the cost of using } \\
\text { technologies }\end{array}$ \\
\hline & $\begin{array}{l}\text { The use of computer resource } \\
\text { problem }\end{array}$ & $\begin{array}{l}\text { the cost of } \\
\text { management }\end{array}$ \\
\hline & $\begin{array}{l}\text { The problem of the distribution } \\
\text { of personnel / employee }\end{array}$ & $\cdots \cdots$ \\
\hline & $\cdots \cdots$ & \\
\hline \multirow{6}{*}{$\begin{array}{l}\text { Progress } \\
\text { problem }\end{array}$} & Problem of develop plan & CCUS develop plan \\
\hline & Problem of test progress & ...... \\
\hline & $\begin{array}{l}\text { Problem of increase } \\
\text { progressively and modify } \\
\text { progress }\end{array}$ & \\
\hline & The problem of milestone & \\
\hline & The problem of productivity & \\
\hline & ...... & \\
\hline \multirow{11}{*}{$\begin{array}{l}\text { Manage quality } \\
\text { problem }\end{array}$} & $\begin{array}{l}\text { Weak in configuring } \\
\text { management }\end{array}$ & $\begin{array}{l}\text { Weak in quality } \\
\text { management }\end{array}$ \\
\hline & Mistake catch demand & Weak in auditing $\ldots . .$. \\
\hline & Wrong structure design & \\
\hline & Wrong coding management & $\begin{array}{l}\text { Weak in configuring } \\
\text { management }\end{array}$ \\
\hline & Wrong test design scheme & $\begin{array}{l}\text { Weak in assessment and } \\
\text { certification }\end{array}$ \\
\hline & Wrong conversion way & ...... \\
\hline & Weak in training management & \\
\hline & $\begin{array}{l}\text { Mistake increase progressively } \\
\text { and modify management }\end{array}$ & \\
\hline & Weak subcontract management & \\
\hline & Lack the base line management & \\
\hline & ...... & \\
\hline
\end{tabular}

We have summarized above-mentioned form frame as simple and practical as possible. In view of the fact that there is more specific content of CMM details, here, we not give unnecessary details again.

Table 3 CMM of CCUS

\begin{tabular}{|l|l|}
\hline Level & Capability \\
\hline Initial & No standard on CCUS \\
\hline Repeatable & Planning and management on KPA of CCUS \\
\hline Defined & Unified standard on CCUS management \\
\hline Managed & CCUS management with engineering technology \\
\hline Optimizing & CCUS management with early warning mechanism \\
\hline
\end{tabular}

In regarding of the CCUS, the researching of the management scope, connotation and content to gain the practice experience in this area and forms a corresponding model has significant meanings for the CCUS developing and the international cooperation. Thus, it is worth to make further researching.

\section{Acknowledgment}

This research was supported by the Beijing philosophical socia 1 science (No. 11JGB077) project; the Beijing Municipal Educ ation Commission Foundation of China (No. KM20111003800 2); the Beijing Natural Science Foundation project (No. 91220 03). This research was supported by the National Natural Science Fo undation (No.71240002)

\section{References}

[1] Hui Ma,Yiping Yang, Research on Quality Appraisal and the Body of Knowledge for Software Quality, Posts \& Telecommunications Press, Beijing, 2009

[2] The Administrative Center for China's Agenda 21 of the Ministry of Science and Technology of the People's Republic of China "Carbon Capture , Utilization and Storage Technology Development in China", September 2011

[3] The Administrative Center for China's Agenda 21 of the Ministry of Science and Technology of the People's Republic of China "Technology Roadmap Study on Carbon Capture, Utilization and Storage in China" , September 2011

[4] PAS 2050:2008 ISO 14067: Carbon Footprint of Products, PPT.

[5] http://www.ccuschina.org.cn/

[6] http://news.cnpc.com.cn/system/2011/01/21/001320394.shtml

[7] http://www.ucl.ac.uk/cclp/ccsdedlegnatoverview.php 